(Table I), was below their detection limit.

All the materials tested except the beverages were analyzed for recovery of spiked levels of $\mathrm{Me}_{2} \mathrm{SO}$ and $\mathrm{Me}_{2} \mathrm{SO}_{2}$. In all cases including spiked blanks, the recovery was in the range of 90-100\%. The reproducibility of the method was found to be in the range of $10-15 \% . \mathrm{Me}_{2} \mathrm{SO}$ and $\mathrm{Me}_{2} \mathrm{SO}_{2}$ were not detected in the solvents or distilled water blanks.

The detection limit of $\mathrm{Me}_{2} \mathrm{SO}$ and $\mathrm{Me}_{2} \mathrm{SO}_{2}$ was $1.2 \mathrm{ng}$ at a signal-to-noise ratio of 2 . This was similar to the value determined by Andreae (1980) of $1 \mathrm{ng}(\mathrm{S})$ as $\mathrm{Me}_{2} \mathrm{SO}$. When a 50-g sample is used, the reported detection limit resulted in being able to detect $0.05 \mathrm{ppm}$ of $\mathrm{Me}_{2} \mathrm{SO}$ and $\mathrm{Me}_{2} \mathrm{SO}_{2}$. Any detectable value below this level was reported as a trace.

For confirmation of the analysis of $\mathrm{Me}_{2} \mathrm{SO}$, samples were sent to Dr. B. F. Hrutfiord at the University of Washington, Seattle, WA. Their concentrations of $\mathrm{Me}_{2} \mathrm{SO}$ in canned corn 2 , tomato paste 2 , and raspberry jam were determined to be $0.16,2.0$, and $2.6 \mathrm{ppm}$, respectively. This is in agreement with the values of $0.14,3.7$, and $1.8 \mathrm{ppm}$, respectively, determined in this study (Table I). The limit of detection determined by Dr. Hrutfiord was $1.2 \mathrm{ng}$ of $\mathrm{Me}_{2} \mathrm{SO}$ with a signal-to-noise ratio of 3 . Mass spectrometry was used to authenticate the presence of $\mathrm{Me}_{2} \mathrm{SO}$.

\section{ACKNOWLEDGMENT}

We thank Doug Nosler of Clark College, Vancouver, WA, for providing laboratory space and Dr. P. C. Crandall of SWWRU for supervising the growing of the crops used in this study.

\section{LITERATURE CITED}

Andreae, M. O. Limnol. Oceanogr. 1980, 25 (6), 1054-1063.

Anness, B. J.; Bamforth, C. W.; Wainwright, T. J. Inst. Brew. 1979, $85,346-349$.
Bentley, M. D.; Douglass, I. R.; Lacadie, J. A.; Whittier, D. R. J. Air Pollut. Control Assoc. 1972, 22 (5), 359-363.

Boyko, A. L.; Morgan, M. E.; Libbey, L. M. "Analysis of Foods and Beverages"; Charalambous, G., Ed.; Academic Press: New York, 1978; pp 57-79.

Canova, L. Congresso International De O'leos Essenciais Rio de Janeiro, Academia Brasileira De Cinencias 44, Oct 11-16, 1971, 273-277.

Dickenson, C. J. Chem. Ind. (London) 1979, 896-898.

Ferretti, A.; Flanagan, P. V. J. Agric. Food Chem. 1972, 20 (3), 695-698.

Kiribuchi, T.; Yamanishi, T. Agric. Biol. Chem. 1963, 27, 56-59.

Lovelock, J. E.; Maggs, R. J.; Rasmussen, R. A. Nature (London) 1972, 237, 452-453.

Lykken, L.; Mitchell, L. E.; Woogerd, S. M. J. Agric. Food Chem. 1957, 5 (7), 501-505.

Miers, J. C. J. Agric. Food Chem. 1966, 14 (4), 419-423.

Self, R.; Casey J. C.; Swain, T. Chem. Ind. (London) 1963, 863-864.

Toan, T. T.; Bassett, R.; Claydon, T. J. J. Dairy Sci. 1965, 48, 1174-1178.

Tressl, R.; Bahri, D.; Holzer, M.; Kossa, T. J. Agric. Food Chem. 1977, 25 (3), 459-463.

Williams, K. I. H.; Burstein, S. H.; Layne, D. S. Arch. Biochem. Biophys. 1966a, 113, 251-252.

Williams, K. I. H.; Burstein, S. H.; Layne, D. S. Proc. Soc. Exp. Biol. Med. 1966b, 122, 865-866.

Williams, K. I. H.; Whittemore, K. S.; Mellin, T. N.; Layne, D. S. Science (Washington, D.C.) 1965, 149, 203-204.

Thomas W. Pearson Howard J. Dawson* Homer B. Lackey

Crown Zellerbach

Chemical Products Division

Camas, Washington 98607

Received for review February 6, 1981. Accepted June 12, 1981.

\title{
Studies on Desi and Kabuli Chickpea (Cicer arietinum L.) Cultivars. 3. Mineral and Trace Element Composition
}

\begin{abstract}
Eight desi and 7 kabuli type chickpea cultivars grown at the ICRISAT Center $\left(17^{\circ} \mathrm{N}\right)$ and at Hissar $\left(29^{\circ} \mathrm{N}\right)$ were analyzed for phosphorus, potassium, calcium, magnesium, zinc, copper, iron, and manganese. Whole seed, dhal (decorticated split cotyledons), and seed coat were analyzed. Except for calcium, zinc, and manganese, the mean values of other mineral elements of desi and kabuli whole seed and dhal samples from both the locations showed no significant differences. Seed coats of kabuli cultivars contained significantly more calcium, zinc, copper, iron, and manganese when grown at both locations and significantly more potassium and phosphorus only when grown at Hissar.
\end{abstract}

In addition to being an important source of protein, legumes are also reported to be a good source of minerals. Meiners et al. (1976) reported the content of nine mineral elements in ten kinds of raw and cooked legumes including chickpea (Cicer arietinum L.). The levels of minerals such as calcium, iron and phosphorus have been studied in the dry seeds of chickpea cultivars (Tiwari et al., 1977) and in developing seeds of chickpea (Lal et al., 1963; Verma et al., 1964).

Recent analyses revealed that seed coat percent and fiber content were the only two constituents that clearly distinguished the desi and kabuli types of chickpea (Jambunathan and Singh, 1980), while the amino acid compo- sition and seed protein fractions of the two types were similar (Singh et al., 1981). Analyses of the mineral and trace element composition of desi and kabuli cultivars are reported in this communication.

\section{MATERIALS AND METHODS}

Seed samples of eight desi (USA-613, 850-3/27, Pant G-114, CPS-1, T-3, Annigeri, BG-203, and P-5462) and seven kabuli (K-4, C-104, Rabat, L-550, GL-629, Giza, and No. 501) cultivars of chickpea grown at the ICRISAT Center (near Hyderabad) $\left(17^{\circ} \mathrm{N}\right.$; soil type vertisol) and at Hissar $\left(29^{\circ} \mathrm{N}\right.$; soil type entisol) were obtained by pooling seeds from single plots and were received from our 
Table I. Mineral and Trace Element Composition of Desi and Kabuli Chickpea Cultivars Grown at the ICRISAT Center ${ }^{a}$

\begin{tabular}{|c|c|c|c|c|c|c|c|c|c|c|}
\hline \multirow[b]{2}{*}{ element } & \multirow[b]{2}{*}{ seed type } & \multicolumn{3}{|c|}{ whole seed, $\mathrm{mg} / 100 \mathrm{~g}$} & \multicolumn{3}{|c|}{$\mathrm{dhal}, \mathrm{mg} / 100 \mathrm{~g}$} & \multicolumn{3}{|c|}{ seed coat, $\mathrm{mg} / 100 \mathrm{~g}$} \\
\hline & & range & mean & $\mathrm{SEM}^{b}$ & range & mean & $\mathrm{SEM}^{b}$ & range & mean & $\overline{\mathrm{SEM}^{b}}$ \\
\hline phosphorus & $\begin{array}{l}\text { desi } \\
\text { kabuli }\end{array}$ & $\begin{array}{l}244-429 \\
268-427\end{array}$ & $\begin{array}{l}334 \\
325\end{array}$ & 22.1 & $\begin{array}{l}265-543 \\
287-419\end{array}$ & $\begin{array}{l}406 \\
354\end{array}$ & 27.8 & $\begin{array}{l}12.0-35.6 \\
15.2-54.2\end{array}$ & $\begin{array}{l}23 \\
28\end{array}$ & 4.0 \\
\hline potassium & desi & $\begin{array}{l}996-1272 \\
988-1333\end{array}$ & $\begin{array}{l}1099 \\
1082\end{array}$ & 41.2 & $\begin{array}{l}840-1123 \\
897-1149\end{array}$ & $\begin{array}{l}978 \\
989\end{array}$ & 33.0 & $764-1361$ & 960 & 121.9 \\
\hline calcium & $\begin{array}{l}\text { desi } \\
\text { kabuli }\end{array}$ & $\begin{array}{l}93-213 \\
102-179\end{array}$ & $\begin{array}{l}169 \\
154\end{array}$ & 12.2 & $\begin{array}{l}33.0-54.2 \\
47.5-82.3\end{array}$ & $\begin{array}{l}42 \\
63\end{array}$ & $3.1^{c}$ & $\begin{array}{l}708-908 \\
1396-2188\end{array}$ & $\begin{array}{l}829 \\
1800\end{array}$ & $80.5^{c}$ \\
\hline magnesium & $\begin{array}{l}\text { desi } \\
\text { kabuli }\end{array}$ & $\begin{array}{l}128-167 \\
137-151\end{array}$ & $\begin{array}{l}152 \\
142\end{array}$ & 4.1 & $\begin{array}{l}108-146 \\
123-139\end{array}$ & $\begin{array}{l}127 \\
133\end{array}$ & 3.4 & $\begin{array}{l}181-329 \\
172-386\end{array}$ & $\begin{array}{l}254 \\
248\end{array}$ & 22.1 \\
\hline $\operatorname{zinc}$ & $\begin{array}{l}\text { desi } \\
\text { kabuli }\end{array}$ & $\begin{array}{l}3.3-4.2 \\
3.3-5.4\end{array}$ & $\begin{array}{l}3.76 \\
4.31\end{array}$ & 0.20 & $\begin{array}{l}3.8-4.8 \\
3.6-5.8\end{array}$ & $\begin{array}{l}4.35 \\
4.59\end{array}$ & 0.21 & $\begin{array}{l}0.71-0.94 \\
0.88-2.22\end{array}$ & $\begin{array}{l}0.86 \\
1.57\end{array}$ & $0.11^{c}$ \\
\hline copper & $\begin{array}{l}\text { desi } \\
\text { kabuli }\end{array}$ & $\begin{array}{l}1.0-2.1 \\
0.8-1.4\end{array}$ & $\begin{array}{l}1.35 \\
1.17\end{array}$ & 0.11 & $\begin{array}{l}0.9-1.5 \\
0.8-1.3\end{array}$ & $\begin{array}{l}1.13 \\
1.04\end{array}$ & 0.07 & $\begin{array}{l}0.25-0.56 \\
0.34-1.14\end{array}$ & $\begin{array}{l}0.39 \\
0.73\end{array}$ & $0.07^{c}$ \\
\hline iron & $\begin{array}{l}\text { desi } \\
\text { kabuli }\end{array}$ & $\begin{array}{l}3.5-7.8 \\
5.1-7.8\end{array}$ & $\begin{array}{l}5.60 \\
6.60\end{array}$ & 0.44 & $\begin{array}{l}4.5-7.4 \\
4.8-6.7\end{array}$ & $\begin{array}{l}5.70 \\
5.70\end{array}$ & 0.33 & $\begin{array}{l}2.3-4.1 \\
8.2-16.8\end{array}$ & $\begin{array}{l}3.23 \\
10.07\end{array}$ & $0.77^{c}$ \\
\hline manganese & $\begin{array}{l}\text { desi } \\
\text { kabuli }\end{array}$ & $\begin{array}{l}2.1-4.1 \\
2.0-9.4\end{array}$ & $\begin{array}{l}2.95 \\
3.66\end{array}$ & 0.67 & $\begin{array}{l}1.3-2.4 \\
1.7-2.8\end{array}$ & $\begin{array}{l}1.81 \\
2.13\end{array}$ & 0.12 & $\begin{array}{l}4.4-11.2 \\
7.0-21.8\end{array}$ & $\begin{array}{l}8.01 \\
14.89\end{array}$ & $1.36^{c}$ \\
\hline
\end{tabular}

$a$ Based on an analysis of eight desi and seven kabuli cultivars. ${ }^{b}$ Standard error of the mean. $c$ Significant at the $5 \%$ level.

Table II. Mineral and Trace Element Composition of Desi and Kabuli Chickpea Cultivars Grown at Hissar ${ }^{a}$

\begin{tabular}{|c|c|c|c|c|c|c|c|c|c|c|}
\hline \multirow[b]{2}{*}{ element } & \multirow[b]{2}{*}{ seed type } & \multicolumn{3}{|c|}{ whole seed, $\mathrm{mg} / 100 \mathrm{~g}$} & \multicolumn{3}{|c|}{$\mathrm{dhal}, \mathrm{mg} / 100 \mathrm{~g}$} & \multicolumn{3}{|c|}{ seed coat, $\mathrm{mg} / 100 \mathrm{~g}$} \\
\hline & & range & mean & $\mathrm{SEM}^{b}$ & range & mean & $\overline{\mathrm{SEM}^{b}}$ & range & mean & $\mathrm{SEM}^{b}$ \\
\hline phosphorus & $\begin{array}{l}\text { desi } \\
\text { kabuli }\end{array}$ & $\begin{array}{l}261-458 \\
282-398\end{array}$ & $\begin{array}{l}325 \\
336\end{array}$ & 19.5 & $\begin{array}{l}266-555 \\
352-565\end{array}$ & $\begin{array}{l}397 \\
422\end{array}$ & 27.3 & $\begin{array}{l}21.2-36.0 \\
30.4-62.7\end{array}$ & $\begin{array}{l}26 \\
48\end{array}$ & $3.2^{c}$ \\
\hline potassium & $\begin{array}{l}\text { desi } \\
\text { kabuli }\end{array}$ & $\begin{array}{l}1006-1159 \\
1005-1184\end{array}$ & $\begin{array}{l}1074 \\
1128\end{array}$ & 20.9 & $\begin{array}{l}884-1120 \\
887-1057\end{array}$ & $\begin{array}{l}966 \\
982\end{array}$ & 25.4 & $\begin{array}{l}674-1108 \\
976-1845\end{array}$ & $\begin{array}{l}830 \\
1217\end{array}$ & $81.9^{c}$ \\
\hline calcium & $\begin{array}{l}\text { desi } \\
\text { kabuli }\end{array}$ & $\begin{array}{l}140-259 \\
125-178\end{array}$ & $\begin{array}{l}191 \\
155\end{array}$ & $11.5^{c}$ & $\begin{array}{l}32.4-65.4 \\
45.1-66.1\end{array}$ & $\begin{array}{l}45 \\
57\end{array}$ & $3.4^{c}$ & $\begin{array}{l}694-1042 \\
1318-1952\end{array}$ & $\begin{array}{l}887 \\
1656\end{array}$ & $72.3^{c}$ \\
\hline magnesium & $\begin{array}{l}\text { desi } \\
\text { kabuli }\end{array}$ & $\begin{array}{l}128-168 \\
129-151\end{array}$ & $\begin{array}{l}142 \\
140\end{array}$ & 4.2 & $\begin{array}{l}89-140 \\
115-139\end{array}$ & $\begin{array}{l}114 \\
126\end{array}$ & 5.7 & $\begin{array}{l}185-288 \\
168-400\end{array}$ & $\begin{array}{l}241 \\
278\end{array}$ & 20.0 \\
\hline zinc & $\begin{array}{l}\text { desi } \\
\text { kabuli }\end{array}$ & $\begin{array}{l}1.5-2.9 \\
2.0-3.1\end{array}$ & $\begin{array}{l}1.96 \\
2.49\end{array}$ & $0.16^{c}$ & $\begin{array}{l}1.9-2.6 \\
2.1-3.3\end{array}$ & $\begin{array}{l}2.24 \\
2.67\end{array}$ & 0.15 & $\begin{array}{l}0.48-0.77 \\
0.93-1.36\end{array}$ & $\begin{array}{l}0.65 \\
1.09\end{array}$ & $0.05^{c}$ \\
\hline copper & $\begin{array}{l}\text { desi } \\
\text { kabuli }\end{array}$ & $\begin{array}{l}0.6-1.3 \\
0.8-1.2\end{array}$ & $\begin{array}{l}0.85 \\
0.96\end{array}$ & 0.07 & $\begin{array}{l}0.6-1.7 \\
0.7-1.1\end{array}$ & $\begin{array}{l}0.85 \\
0.91\end{array}$ & 0.10 & $\begin{array}{l}0.21-0.35 \\
0.34-0.68\end{array}$ & $\begin{array}{l}0.27 \\
0.54\end{array}$ & $0.03^{c}$ \\
\hline iron & $\begin{array}{l}\text { desi } \\
\text { kabuli }\end{array}$ & $\begin{array}{l}3.0-9.8 \\
5.9-7.3\end{array}$ & $\begin{array}{l}7.26 \\
6.66\end{array}$ & 0.64 & $\begin{array}{l}4.9-6.5 \\
5.1-6.2\end{array}$ & $\begin{array}{l}5.73 \\
5.59\end{array}$ & 0.17 & $\begin{array}{l}3.7-5.6 \\
7.0-11.9\end{array}$ & $\begin{array}{l}4.58 \\
9.54\end{array}$ & $0.45^{c}$ \\
\hline manganese & $\begin{array}{l}\text { desi } \\
\text { kabuli }\end{array}$ & $\begin{array}{l}2.3-3.4 \\
2.5-6.5\end{array}$ & $\begin{array}{l}2.88 \\
3.26\end{array}$ & 0.37 & $\begin{array}{l}1.5-1.9 \\
1.6-2.2\end{array}$ & $\begin{array}{l}1.65 \\
1.89\end{array}$ & $0.06^{c}$ & $\begin{array}{l}4.1-12.2 \\
12.2-18.5\end{array}$ & $\begin{array}{l}8.84 \\
14.90\end{array}$ & $0.91^{c}$ \\
\hline
\end{tabular}

$a$ Based on an analysis of eight desi and seven kabuli cultivars. ${ }^{b}$ Standard error of the mean. $c$ Significant at the $5 \%$ level.

chickpea breeders. Whole seed, dhal (decorticated split cotyledons), and seed coat samples were obtained as described earlier (Jambunathan and Singh, 1980). All results are expressed on a dry weight basis.

Samples for the determination of mineral contents were digested in a block digestor by using a nitric acid-sulfuric acid-perchloric acid mixture according to Piper (1966) and were analyzed for potassium, calcium, magnesium, zinc, copper, iron, and manganese by using an atomic absorption spectrophotometer (Varian Techtron, Model-1200). Phosphorus in the digested aliquots was estimated according to the standard colorimetric procedure (Koenig and Johnson, 1942).

\section{RESULTS AND DISCUSSION}

The ranges, mean values, and standard error of the mean of the mineral elements in the whole seed, dhal, and seed coat components of desi and kabuli cultivars grown at the ICRISAT Center are shown in Table I. The mean mineral and trace element composition of desi and kabuli whole seed samples did not differ significantly, while calcium showed a significant difference in the case of dhal samples. However, when the mineral and trace element compositions of the seed coats were examined, the mean values of calcium, zinc, copper, iron, and manganese from the desi and kabuli types differed significantly. The ranges of calcium values in desi $(708-908 \mathrm{mg} / 100 \mathrm{~g})$ and kabuli
(1396-2188 $\mathrm{mg} / 100 \mathrm{~g})$ and of iron in desi $(2.3-4.1 \mathrm{mg} / 100$ g) and kabuli $(8.2-16.8 \mathrm{mg} / 100 \mathrm{~g})$ showed clear-cut differences (Table I).

The results of the analyses obtained for samples grown at Hissar, which lies in a major chickpea growing area, were similar to those obtained from Hyderabad (Table II). Mean values of elements analyzed for desi and kabuli whole seed showed significant differences in the case of calcium and zinc, while dhal samples showed significant differences in the case of calcium and manganese. In addition to the five elements that showed statistically distinct differences in the case of seed coat samples grown at the ICRISAT Center, two additional elements, phosphorus and potassium, were also observed to be different $(p<0.05)$. Here again the differences in the case of iron and calcium were particularly large.

The effects of location on the mineral contents appeared to be low. The mean values of zinc and copper in the case of both desi and kabuli cultivars were higher in samples obtained from the ICRISAT Center than in the Hissar samples. Calcium was the predominant mineral of chickpea seed coats and accounted for $\sim 65 \%$ of the total calcium in the whole seeds. Similar observations have been reported earlier for chickpea (Lal et al., 1963) and other legumes (Singh et al., 1968).

In India, a greater proportion of the chickpea is consumed after the removal of seed coat. Calcium has been 
reported to be one of the nutrients that is deficient in the diets of low-income people, particularly infants, preschool children, and pregnant and lactating women. Therefore, the loss of calcium in the form of seed coat will have greater nutritional implications. Consumers should therefore be encouraged to eat whole chickpea and attempts should be made to study the bioavailability of calcium from the seed coat.

\section{ACKNOWLEDGMENT}

We thank Jagdish Kumar for providing the seed material and R. Seetha and C. D. Ramaiah for technical assistance.

\section{LITERATURE CITED}

Jambunathan, R.; Singh, U. Proc. Int. Workshop Chickpea Improv., 1979 1980, 61-66.

Koenig, H. A.; Johnson, C. R. Ind. Eng. Chem., Anal. Ed. 1942, $14,155$.

Lal, B. M.; Prakash, V.; Verma, S. C. Experimentia 1963, 19, $154-155$.
Meiners, C. R.; Derise, N. L.; Lau, H. C.; Crews, M. G.; Ritchey, S. J.; Murphy, E. W. J. Agric. Food Chem. 1976, 24, 1126-1130.

Piper, C. S. In "Soil and Plant Analysis"; Hans Publisher: Bombary, India, 1966; p 272.

Singh, S.; Singh, H. D.; Sikka, K. C. Cereal Chem. 1968, 45, 13-18.

Singh, U.; Raju, S. M.; Jambunathan, R. J. Food Sci. Technol. 1981, 18, 86-88.

Tiwari, S. R.; Sharma, R. D.; Ram, N. J. Agric. Food Chem. 1977, $25,420-421$.

Verma, S. C.; Lal, B. M.; Prakash, V. J. Sci. Food Agric. 1964, $15,25-31$.

Ramamurthi Jambunathan* Umaid Singh

International Crops Research Institute for the Semi-Arid Tropics (ICRISAT)

ICRISAT Patancheru P.O., 502 324, A.P., India

Received for review November 6, 1980. Accepted May 4, 1981. Submitted as Journal Article No. 158 by the International Crops Research Institute for the Semi-Arid Tropics (ICRISAT).

\title{
Gas Chromatography-Mass Spectroscopy Identification of Volatiles from Rancid Oat Groats
}

\begin{abstract}
A systematic GC-MS study of the volatiles present in oxidatively rancid oat groats is presented. Autooxidation compounds expected from the fatty acid composition of oats (high linoleic content) were observed. The most abundant volatiles found were hexanal, pentanal, 1-pentanol, and 3,5-octadien-2-one. A total of 45 compounds were identified, including 24 aldehydes, ketones, and alcohols probably arising from lipid autooxidation.
\end{abstract}

The oxidative stability of oatmeal is good and wellknown. In contrast, some other processed oat products develop rancidity quite quickly (Martin, 1958). The highly unsaturated fat content (4-11\%) of oats is usually cited as the cause for these problems. To our knowledge there has not been a systematic study of the volatiles present in rancid oat products to fully document these conclusions.

Fritsch and Gale (1977) showed that rancid odors occurred in ready-to-eat oat cereals when the hexanal concentration reached 5-10 $\mathrm{ppm}$. The appearance of rancidity in oat products or ready-to-eat cereals is suspected to be primarily due to autooxidation rather than enzymatic activity because of the very low moisture content of the cereal systems. Heimann et al. (1975) showed volatile aldehydes including $(E)$-2-nonenal were produced by incubation of linoleic acid with oat lipoxygenase. Heydanek and McGorrin (1980) reported carbonyls including hexanal, pentanal, 2,4-decadienal, and benzaldehyde were present in the volatiles of cooked oatmeal. The present study was undertaken to define the volatile components present in a noticeably rancid oat groat system in order to help define the cause and possible mechanism of the rancidity.

\section{EXPERIMENTAL SECTION}

Materials. Dried oat groats (A grade) were obtained from commercial production streams at $7.5 \%$ moisture and had a typical flavor. The groats were boiled for $30 \mathrm{~min}$ in distilled water, drained, freeze-dried overnight, and stored in polyethylene bags at ambient temperatures.
Within 1 week noticeable rancidity odors were observed, and when analyzed at 3 weeks of age, the oats had a pronounced rancid, "old chicken fat" aroma.

All standard flavor chemicals were purchased from commercial sources (e.g., Aldrich Chemical Co.) and verified by GC-MS analysis.

Volatile Isolation. Rancid oat groats $(2 \mathrm{~kg})$ were mixed with $6 \mathrm{~L}$ of distilled water in a 12-L flask. The flask was immersed in a $55^{\circ} \mathrm{C}$ water bath and vacuum distillation at 30 torr carried out for $2 \mathrm{~h}$. Condensation was accomplished in a series of traps immersed in dry ice-2-propanol. The resulting $1 \mathrm{~L}$ of distillate water was made $20 \%(\mathrm{w} / \mathrm{v})$ with $\mathrm{NaCl}$ and extracted $5 \times 100 \mathrm{~cm}^{3}$ with $\mathrm{CH}_{2} \mathrm{Cl}_{2}$. The organic extract was dried with $\mathrm{Na}_{2} \mathrm{SO}_{4}$ and reduced to a 5- $\mathrm{cm}^{3}$ volume in a Kudurna-Danish concentrator. The extract was held at $0^{\circ} \mathrm{C}$ until analyzed.

GC-MS Analysis. The volatiles obtained were analyzed by GC-MS using the following system. Separation with an H-P 5840GC was done on a $50 \mathrm{~m} \times 0.5 \mathrm{~mm}$ i.d. Pyrex WCOT column coated with SE-30. Temperature was programmed from $40^{\circ} \mathrm{C}$, after a 3-min initial hold, to $170^{\circ} \mathrm{C}$ at $3^{\circ} \mathrm{C} / \mathrm{min}$. The $\mathrm{GC}$ effluent was split to an H-P 5980A mass spectrometer via a Pt-Ir open split. The data were acquired on an H-P 5933 disc drive data system. Electron ionization was at $70 \mathrm{eV}$.

Kovats retention index values were obtained by spiking a series of $n$-alkanes into a portion of the oat groat volatiles. Comparison of standard compound retention times were also obtained by coinjection with the $n$-alkane series. 